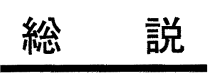

\title{
古細菌エーテル脂質の多様性と系統関係
}

\author{
古 賀 洋 介 \\ 産業医科大学・医学部・生体物質化学教室 \\ （干807 北九州市八幡西区医生が丘 1-1）
}

\section{Structural Diversity of Archaeal Ether Lipid and Phylogenetic Relationship}

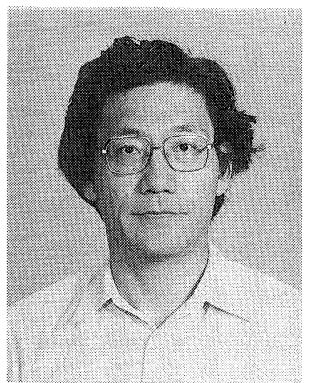

Yosuke KOGA

Department of Chemistry

University of Occupational and Environmental Health

(Yahatanishi-ku, Kitakyushu-shi, =807)

\begin{abstract}
Ether lipid is one of the most distictive markers that discriminate Archaea and Bacteria. Among Archaea, there are diversity in their core lipid structure, phosphate-containing polar-head groups, and glycolipid-sugar moieties. For example, non-methaogenic thermophilic Archaea contain mainly tetraether type core and inositol as a sole phosphate-containing polar-head group, lipids of extreme halophiles are composed of only diether type core lipid and glycerophosphate and its derivatives as polar head groups, and all methanogens so far analyzed are characterized by the presence of nitrogen-containing polar groups. The diversity of lipids in Archaea is not random but is determined by a phylognetic relationship. Therefore qualitative lipid composition is used as a chemotaxonomic marker of extreme halophiles and methanogens. The most fundamental phenotypic marker that distinguishes Archaea and Bacteria, which is the highest taxonomic rank of living organisms, is the enantiomeric difference of glycerophosphate backbone structure of their polar lipids. It could be assumed that this difference has been kept since the time when organisms of the two domains had been differentiated.
\end{abstract}

Key words : archae bacteria, ether lipid, phylogeny, chemotaxonomic marker, sn-glycerol-1 -phosphate

\section{1 エーテル脂質の生物界での分布}

エーテル脂質は古細菌とその他の生物を識別する最も はっきりしたマーカーのひとつである。古細菌の脂質は 確かにグリセロールと炭化水素鎖のすべての結合がエー テル結合である。しかし，グリセロールと炭化水素鎖が エーテル結合で結ばれた脂質は真正細菌にも真核生物に も一部ではあるが存在し, 古細菌だけのものではない (Fig. 1)。真核生物では, ほ(哺)乳類や鳥類の脳組織, アンチョビーなどの魚類, イカなどの軟体動物, Tetrahymena などの原生動物などに 1-アルキル-2-ア シルーグリセロホスホコリン (1-アルキル-2-アシルGPC), 1-アルキル-2-アシル-グリセロホスホエタノー ルアミン (1-アルキル-2-アシル-GPE), 1-アルキル-2アシルーグリセロホスホセリン (1-アルキル-2-アシル-
GPS) などのエーテルリン脂質がリン脂質の 1 数十\% 存在している ${ }^{1) \sim 4) 。 ま た, ~ 1-ア ル ク-1 '-エ ニ ル-2-ア シ ~}$ ル-GPC, 1-アルク-1'-エニル-2-アシル-GPE, 1-アル ク-1'-エニル-2-アシル-GPS などのプラスマローゲン 型リン脂質も多い場合には数十\%存在している1) 4)。 植物にもプラスマローゲン型リン脂質が存在するとい う。真正細菌の場合は, プラスマローゲン型と 1 -アル キル-2-アシル型脂質は嫌気性細菌にだけ分布してい る5)。その量はプラスマローゲン型で全リン脂質の 9

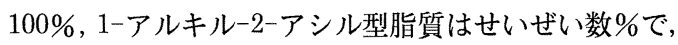
真核生物における含有量と似ている ${ }^{1)}$ 。好気性細菌には 一般的にはどちらのエーテル脂質も存在しない。好熱性 真正細菌である Thermodesulfotobacterium commune $^{6)}$ や Aquifex pyrophilus ${ }^{7)}$ などにはグリセロー ル骨格と 2 本の炭化水素鎖の結合が両方ともエーテル結 
a<smiles>[R]COC[C@H](COP(=O)(O)OC[CH]N)OC(=O)C[R]</smiles>

b<smiles>[R]C=CO[C@H](COC(=O)C[R])COP(=O)(O)OC[CH][14CH3]</smiles>

c

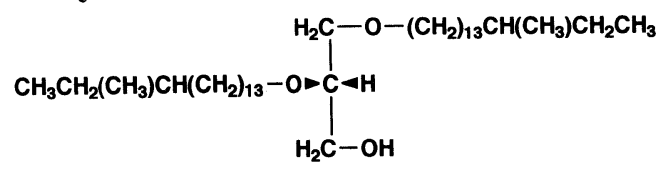

d

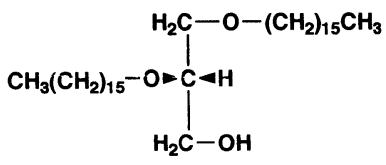

Fig. 1 Eucaryal and Bacterial Ether Lipids.

a) 1-alkyl-2-acyl-sn-glycerol-3-phosphocholine ; b) 1-alk-1'-enyl-2-acyl-sn-glycerol-3-phosphocholine (plasmalogen) ; c) 1,2-di-O-anteisoheptadecyl-sn-glycerol (bacterial diether lipid from Thermodesulfotobacterium $^{6}$ ) ; d) 1,2-di-O-hexadecyl-sn-glycerol (bacterial diether lipid from Aquifex pyrophilus ${ }^{7)}$ ).

合であるジエーテル脂質が見いだされた。古細菌のエー テル脂質に関する小文の冒頭にこのような古細菌以外の エーテル脂質のことを述べるのは, エーテル脂質が古細 菌に限って存在するものではないこと, しかし, 古細菌 のエーテル脂質は他の生物のエーテル脂質とは異なった 特徵を持っていること, その特徴を明確に認識するため に, 単にエーテル型＝古細菌という図式をもっと精密に しなくてはならないことを強調するためである。

これらのエーテル脂質の特徵は古細菌のエーテル脂質 の炭化水素鎖がイソプレノイドであるのとは対照的に, 炭化水素鎖が脂肪酸に由来する直鎖のものか, モノメチ ル分枝のものであり，炭化水素鎖の結合位置が真核生物 のジアシル型脂質と同じく $s n-1$ 位, $s n-2$ 位である。こ れらの特徴が古細菌の脂質を他の生物の脂質から区別す る際だった特徴であることを明確にしておかなければな らない。

\section{2 古細菌エーテル脂質の 4 つの特徵}

古細菌のエーテル脂質を真正細菌, 真核生物のグリセ
ロリン脂質と比較したとき, 次の 4 点の特徵を指摘する ことができる(Fig. 2)。

1）グリセロール骨格と炭化水素鎖の結合がすべて エーテル結合である。真正細菌などではこれは, 上述の ような例外もあるが, 基本はエステル結合である。

2) 炭化水素鎖がイソプレノイドである。真正細菌な どでは脂肪酸である。イソプレノイドも脂肪酸もアセチ ル CoA を出発物質として合成されるが，イソプレノイ ドはメバロン酸を経由して炭素 5 原子からなる単位が付 加して伸張していくのに対し, 脂肪酸は炭素 2 原子から なる単位で伸張していく。このように現行の生化学的合 成経路では両者は著しく異なる経路で合成される炭化水 素鎖である。

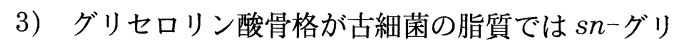
セロール-1-リン酸 $(\mathrm{G}-1-\mathrm{P})$, 真正細菌と真核生物では $s n$-グリセロール-3-リン酸 $(\mathrm{G}-3-\mathrm{P})$ であり, 両者は対 掌体の関係にある。つまり 2 位の炭素原子の周囲に関し て反対の立体構造を持っている。

4）古細菌にはジエーテル型の脂質 2 分子が炭化水素 鎖の末端で縮合した構造のテトラエーテル型脂質が広く 存在している。テトラエーテル型の脂質は膜内では $2 つ$ の極性基を膜の両側に配置して単分子膜を形成している といわれている。これに対して，他の生物の脂質にはこ のような雨極性の脂質は一般的には存在しない。

これらの 4 つの特徵は一般的なものであって一部に例 外はある。なお，極性脂質の極性基（糖脂質の糖鎖部分 やリン脂質のリン酸含有極性基）を化学的に除去した残 りの部分（O-アルキルグリセロールエーテル）をコア 脂質と称する。また, ジエーテル型およびテトラエーテ ル型のコア脂質に我々はそれぞれアーキオール (archaeol), カルドアーキオール (caldarchaeol) という名 称を与えている ${ }^{8)}$ 。その他の古細菌の脂質の命名法につ いては原報を参照されたい ${ }^{8)}$ 。以下の記述にこの名称を 使うことにする。

\section{3 非メタン生成好熱性古細菌のエーテル脂質 特徵}

メタン生成しない好熱性古細菌は 16 S rRNA による 系統分類学的には Sulfolobales, Thermoproteales な どの Crenarchaeota (Archaea の中の kingdom のひ とつ) と, Thermococcales, Archaeoglobus, Thermoplasma などの Euryarchaeota (Archaea の中の もうひとつの kingdom) にまたがって存在する9)。こ れらのうち, Sulfolobales に属する好熱好酸菌の脂質 構造が, Langworthy $ら^{10)}$, DeRosa $ら^{11)}$, 伊藤 $\check{1}^{12)}$ によって最もよく解析されている。これらについて詳細 は本特集の須貝らの論文に述べられるので, ここでは概 括的な特徴にふれるにとどめる。コア脂質はテトラエー 


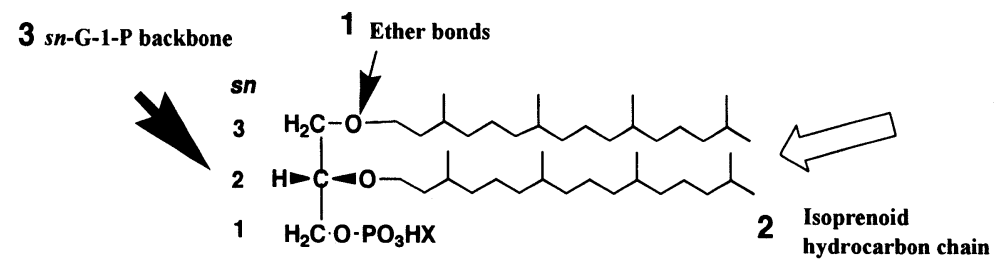

\section{Archaea}

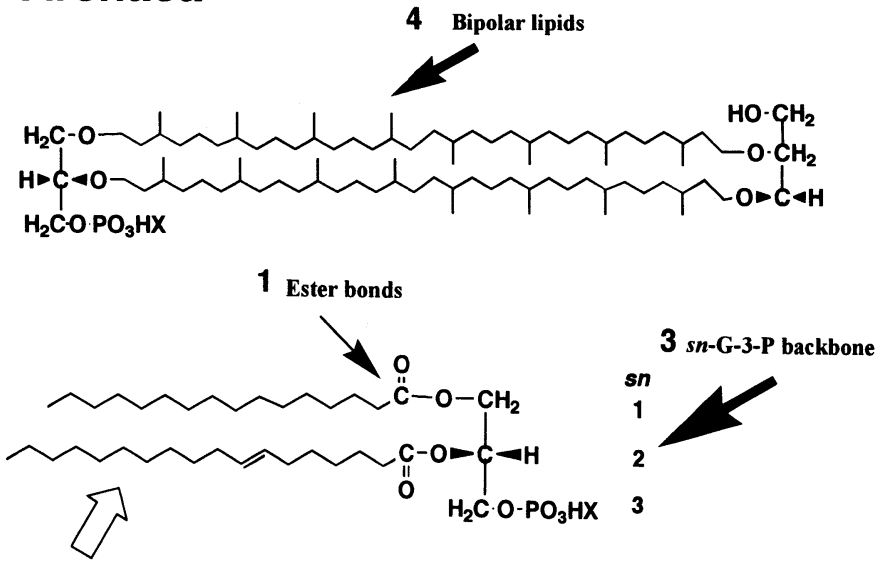

2 Straght chain

Bacteria

Fig. 2 Four Characteristic Features of Polar Lipids that are Different between Archaea and Bacteria.

テル型が大部分を占めるものが多いが, Thermococcus のようにジエーテル型だけであるものもある ${ }^{13)}$ 。ま た, 超好熱性古細菌としては新奇な好気性のAeropyrum pernix のコア脂質はすべて $\mathrm{C}_{25}$ のイソプレノイド からなるアーキオールだけである点は従来知られている 好熱性古細菌にはない脂質構造である ${ }^{14)}$ 。Sulfolobus にはグリセロールの代わりに炭素 9 原子を含むポリオー ル（カルジトール）がエーテル結合に関与して骨格を形 成している脂質がある ${ }^{12)}$ 。さらにシクロペンタン環を 1 〜4 個含むイソプレノイド炭化水素鎖の存在もこの菌の

b
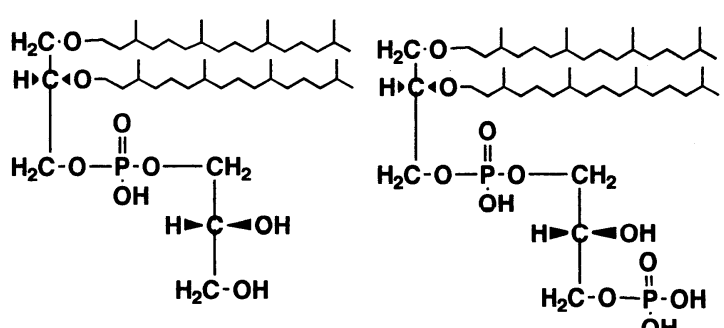

特徴である。リン酸含有極性基は Thermoplasma に はグリセロール（コア脂質に含まれるものではなく, エーテル結合に関与しない極性頭部として存在するもの をさす）がある ${ }^{15)}$ が，それ以外の菌ではイノシトール だけがリン酸含有極性基をなしていて，この点ではきわ めて単純である。しかし, 糖脂質の糖鎖はきわめて複雑 である。

\section{4 高度好塩古細菌のエーテル脂質の特徵}

高度好塩菌の極性脂質のコア脂質はジエーテル型の d

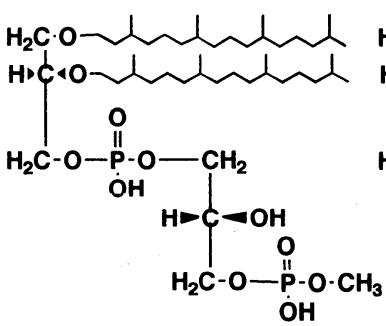

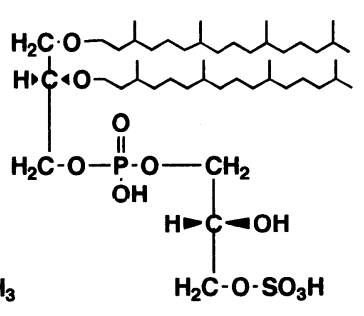

Fig. 3 Structure Diversity of Halobacterial Phospholipids.

a) archaetidylglycerol ; b) archaetidylglycerophosphate ;

c) archaetidylglycero(methyl)phosphate ; d) archaetidyl-

glycerosulfate. 

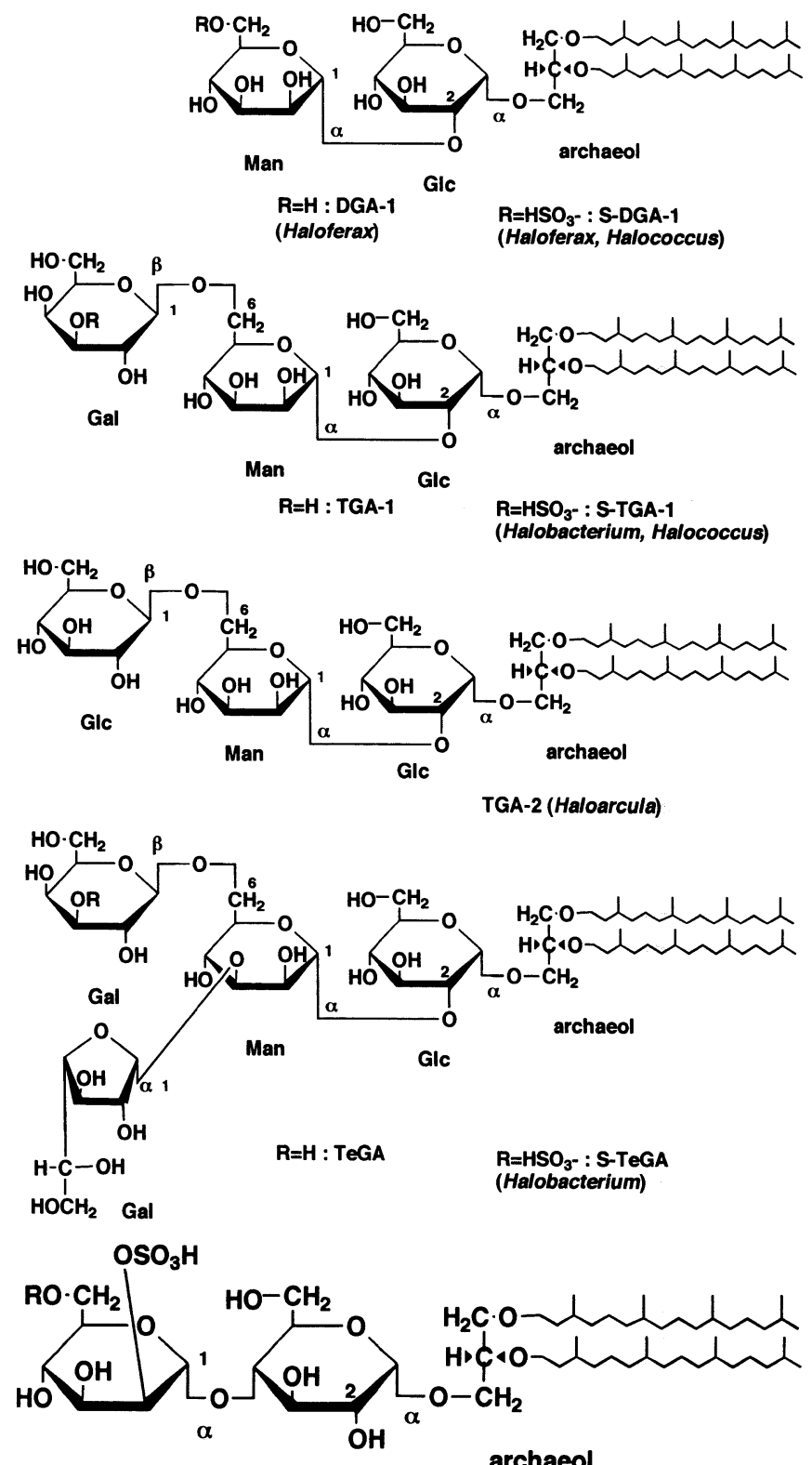

Man

GIc

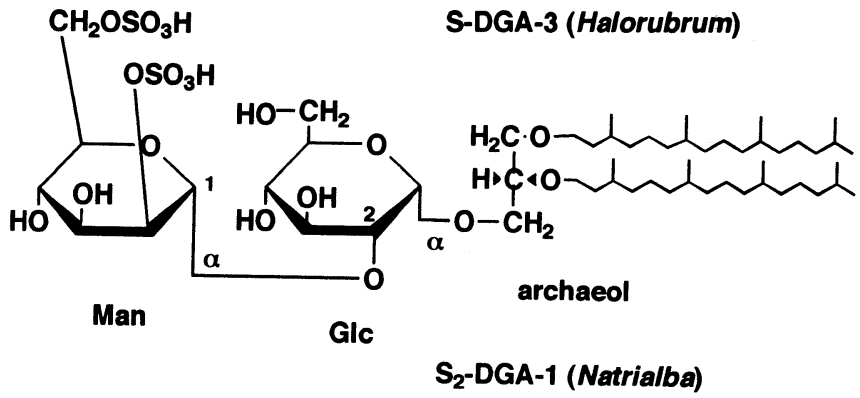

Fig. 4 Structure Diversity of Halobacterial Glycolipids. 
アーキオールだけ16)で, 高度好塩菌にはテトラエーテ ル型の脂質はこれまでに見いだされていない。

イソプレノイド鎖の長さは Halobacterium, Haloarcula など中性菌では $\mathrm{C}_{20}$, Natronobacterium, Natronococcus など好アルカリ菌では $\mathrm{C}_{20}$ と $\mathrm{C}_{25}$ の両 方が存在する ${ }^{16)}$ 。リン酸含有極性基はグリセロールと その誘導体だけで (Fig. 3) ${ }^{16), 17), ~ イ ノ シ ト ー ル や ア ミ ~}$ ノ基含有化合物はない。糖脂質はコア脂質の $s n-1$ 位に $\alpha$-マンノシル-(1-2)- $\alpha$-グルコシル基が結合したものが 共通の根幹をなしている。マンノシル基の 3 位, 6 位に ガラクトースやグルコース, さらにその硫酸エステル化 されたものなどが結合している (Fig. 4) ${ }^{16)}$ 。

\section{5 高度好塩古細菌におけるエーテル型 糖脂質の分布}

高度好塩菌の分類のマーカーとして極性脂質組成が利 用されている。極性脂質の構造は完全に解析されてお り, 分類学的に簡便に調べるには TLC の移動度で判定 できるので, 菌体から抽出した全脂質を 1 回の TLCに かけて各スポットの呈色反応と $R_{f}$ 值の比較だけで必要 な情報は得られる ${ }^{18)}$ 。中性の高度好塩菌はアーキチジ ルグリセロール (archaetidylglycerol) とアーキチジ ル(メチル)グリセロリン酸 [archaetidyl (methyl) glycerophosphate]を共通して持っている。従ってこれ らは分類のマーカーにはならない。リン脂質で分類群に 特徵的なのはアーキチジルグリセロ硫酸 (archaetidylglycerosulfate, AGS) であり, Halobacterium 属と Haloarcula 属の好塩菌には AGS があり, その他の属 の菌にはこの硫リン脂質はない ${ }^{19)}$ 。高度好塩菌の分類 で大きな役割を果たしている脂質は糖脂質である。糖脂

a
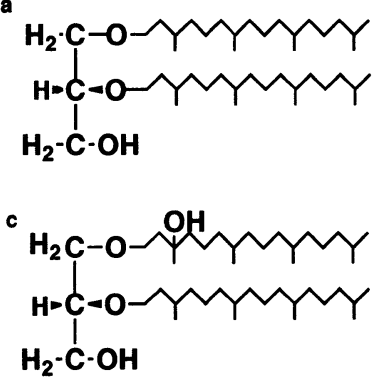

質の種類は高度好塩菌の属レベルで特徴的な組成を示 $す^{19)}$ 。Halobacterium 属の好塩菌は三糖単位をもつ糖 脂質 (TGA-1) と硫酸化された三糖脂質 (S-TGA-1) と四糖脂質 (S-TeGA) の存在で特徵づけられる。 Haloarcula 属の好塩菌は TGA-1 のガラクトースをグ ルコースに置き換えた糖脂質 (TGA-2) が存在すること が特徵である。Haloferax 属の場合は硫酸化された二 糖脂質 (S-DGA-1) とそれの硫酸基のないもの (DGA -1) を持ち, Halococcus 属の場合は硫酸化された二糖 脂質 (S-DGA-1) と硫酸化された三糖脂質 (S-TGA-1, Halobacterium 属と共通) がある。新しく分類された 中性高度好塩菌の属である Halorubrum 属ではマン ノースとグルコースが 1-4 結合と通常とは異なる結合 位置の, 硫酸化された二糖脂質 (S-DGA-3) が特徴的 である (Fig. 4)。Natronobacterium 属と Natronococcus 属の好アルカリ好塩菌は糖脂質をほとんど持っ ていない。

\section{6 メタン生成古細菌のエーテル脂質の特徴 ${ }^{20)}$}

メタン菌の脂質は骨格としてジェーテル型とテトラ エーテル型の両方をもつ菌種とジエーテル型だけのもの とがある。テトラエーテル型のコア脂質はシクロペンタ ン環もカルジトールもなく, 通常のものが大部分である が, 最近テトラエーテル型の骨格で炭化水素鎖の中央付 近で 2 本の炭化水素鎖が共有結合した形の，いわゆる $\mathrm{H}$ 字型コア脂質が超好熱性の Methanothermus fervidus から発見された（森井ら，未発表デー夕）。一方, シ エーテル型コア脂質にはさまざまな変種が知られている (Fig. 5)。すなわち, 通常のものの他, 2 本の炭化水素 鎖の末端が結合して大きな環状になったもの（マクロサ

\section{b}

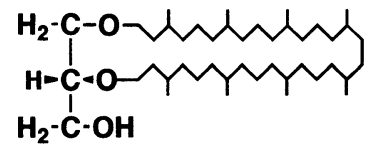

d

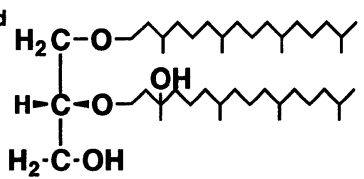

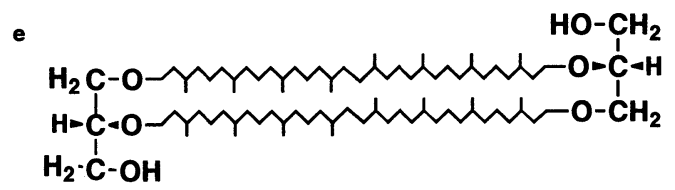

Fig. 5 Structure Diversity of Methanogen Core Lipids.

a) archaeol ; b) macrocyclic archaeol ; c) $\alpha$-hydroxyarchaeol ; d) $\beta$-hydroxyarchaeol; e) caldarchaeol. 
イクリックアーキオール), グリセロールの $s n-3$ 位 ( $\alpha$ 位）または $s n-2$ 位（ $\beta$ 位）の炭化水素の 3'位にヒド ロキシル基が結合したもの（ $\alpha$-ヒドロキシアーキオー ルまたは $\beta$-ヒドロキシアーキオール) などがある。

メタン菌の脂質の極性頭部基は他の古細菌のものと異 なり, 窒素含有原子団 (エタノールアミン, セリン, $N$-アセチルグルコサミンやアミノペンタンテトロール など）が広く見いだされる。イノシトールもグリセロー ルも極性頭部として存在し, 好熱性古細菌や高度好塩菌 との共通性も見られる。

\section{7 メタン生成細菌におけるエーテル脂質 構成部品の分布}

メタン菌の脂質は上述のようにジエーテル型とテトラ エーテル型, あるいは通常のジエーテル型とヒドロキシ ル基を持つジエーテル型, 通常のジエーテル型とマクロ サイクリックなジエーテル型など 2 種類以上のコア脂質 があり，それらのコア脂質にそれぞれ同じ極性基が結合 したり，テトラエーテル型の場合には両側のグリセロー ル残基にそれぞれ極性基が結合することによって多数の 組み合わせが存在し，極性脂質の種類は 20 種以上にの ぼることも珍しくない $\left(\right.$ ヘプタッド説21) ${ }^{21)}$ このように 多数の脂質があると, 全脂質を 2 次元 TLC で展開した
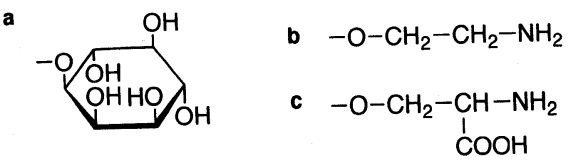

d<smiles>COC(CN(C)C)C(O)CO</smiles>
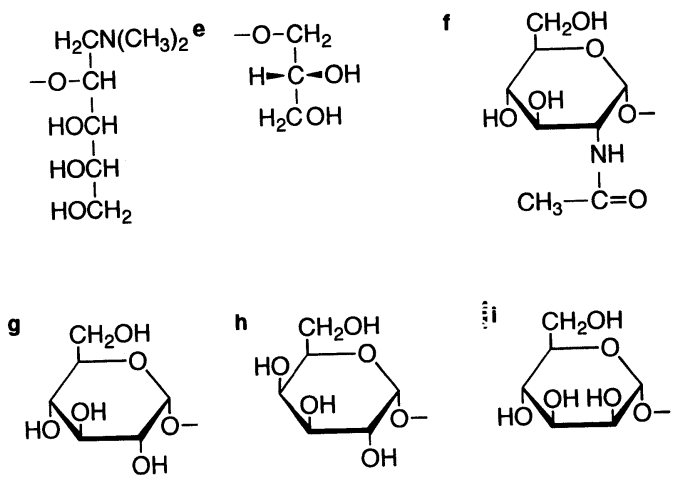

Fig. 6 Structures of Phosphate-containing Polar -head Groups (a-f) and Glycolipid Sugars ( $\mathrm{g}-\mathrm{i})$ from Methanogens.

a) myo-inositol ; b) ethanolamine ;

c) L-serine ; d) $N, N$-dimethylaminopentanetetrol ; e) glycerol ; f) $N$-acetylglucosamine ; g) glucose ; h) galactose ;

i) mannose.
だけでは個々の脂質を簡便に同定することは困難であ る。従って, 高度好塩菌の場合のように全脂質の TLC パターンを比較して分類に用いることはあいまい(曖昧) さがつきまとい，現実的でない。そこで，我々は極性脂 質の構成部品をコア脂質部分とリン酸含有極性基, 糖の 3 部分に分け，それぞれを同定することによって，大ま かにその菌の脂質構成を推定することにした ${ }^{22)}$ 。極性 脂質の構造は上述のようにこれら構成部品の組み合わせ でできあがっていることを考えれば，その菌の脂質の構 造は構成部品の分析でおよその見当をつけられる。この ような簡便法は多数の菌株の脂質を分析しなければなら ない分類学的研究には有効な方法である。菌体から抽出 した全脂質を三分し，ひとつはアセトリシスまたは HF 分解と弱メ夕ノリシスで極性基を除去し，TLC または 蛍光標識した後に HPLC で分析同定した。二番目の試 料は酸性メ夕ノリシスにより糖鎖を単糖まで分解し，還 元後アセチル化して GLC で分析同定した。最後の試料 は $\mathrm{BCl}_{3}$ でエーテル結合 (と糖鎖) を分解して, 極性基 をつけたままのグリセロリン酸エステルを調製し, 電気 泳動と TLCにより極性基の種類によって分離して同定 した。これまでに分析した 30 数種のメタン菌のいずれ かに見いだされた脂質部品の構造を Fig. 5 と Fig. 6 に 示す。これら脂質構成部品のすべてが 1 種類のメタン菌 に存在することはなく, 1 種のメタン菌にはせいぜいコ ア脂質 $2 \sim 3$ 種, 極性基 $1 \sim 5$ 種, 糖 $1 \sim 3$ 種である。これ らの組み合わせがメタン菌の科または属ごとに一定して おり, かつ特徴的であることが明らかになった (Table 1)。各科の特徴的な脂質部品構成は次の通り。なお, こ こで用いたメタン菌の分類体系と分類群の名称はまだ正 式のものにはなっていないが, Boone らの 16 S rRNA

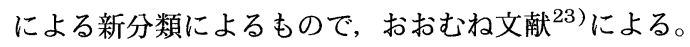
Boone らは $16 \mathrm{~S}$ rRNA の配列比較を主な基準にして メタン菌の分類体系を改め, 新しく多くの目, 科, 属を 創設した。これらの新分類は Methanosarcinales, Methanocaldococcaceae, Methanothermococcus の 新設などの点で脂質構成部品分析によるグループ分けと よく対応する (Fig. 7)。

Methanobacteriaceae : カルドアーキオールがあり, 糖脂質にはグルコースしか含まれていず，リン酸含有極 性基にイノシトール，セリンが共通に見いだされる。エ タノールアミンとヒドロキシアーキオールは一部の属に 存在する。従って, この二つの存否によって属の識別が 可能になる。カルドアーキオール, グルコース, イノシ トールが結合したリン糖脂質がこの科のメタン菌に特徴 的に大量に存在し, TLC でもはっきり識別できるた め, これがこの科のメタン菌のマーカー脂質になってい る。

Methanothermaceae : この科のメタン菌は 1 種 1 株 
Table 1 Family and Genus-specific Distribution of Lipid Component Parts in Methanogens.

\begin{tabular}{|c|c|c|c|c|c|c|c|c|c|c|c|c|c|}
\hline \multirow{2}{*}{$\begin{array}{l}\text { Family } \\
\text { Genus }\end{array}$} & \multicolumn{4}{|c|}{ Core lipid } & \multicolumn{4}{|c|}{ Sugar } & \multicolumn{5}{|c|}{ Polar head group } \\
\hline & Ar & $\mathrm{CA}$ & $\mathrm{Hy}$ & $\mathrm{Mc}$ & Glc & Gal & Man & GlcNAc & Ino & EtN & Ser & Gro & APT \\
\hline \multicolumn{14}{|l|}{ Methanobacteriaceae } \\
\hline Methanobacterium & + & + & - & - & + & - & - & - & + & + & + & - & - \\
\hline Methanobrevibacter & + & + & - & - & + & - & - & - & + & - & + & - & - \\
\hline Methanosphaera & + & + & + & - & + & - & - & - & + & - & + & - & - \\
\hline Methanothermaceae & + & + & - & - & + & - & - & + & + & - & - & - & - \\
\hline \multicolumn{14}{|l|}{ Methanococcaceae } \\
\hline Methanococcus & + & - & + & - & + & - & - & + & - & \pm & + & - & - \\
\hline Methanothermococcus & + & + & + & - & + & - & - & + & - & - & + & - & - \\
\hline Methanocaldococcaceae & + & + & - & + & + & - & - & + & - & + & + & - & - \\
\hline Methanomicrobiaceae & + & + & - & - & + & + & - & - & - & - & - & + & + \\
\hline Methanocorpusculaceae & + & + & - & - & + & + & - & - & - & - & - & + & + \\
\hline Methanospirillaceae & + & + & - & - & + & + & - & - & - & - & - & + & + \\
\hline \multicolumn{14}{|l|}{ Methanosarcinaceae } \\
\hline Methanosarcina \& others & + & - & + & - & + & \pm & - & - & + & + & \pm & + & - \\
\hline Methanosalsus & + & + & + & - & + & - & - & - & + & + & + & + & - \\
\hline \multicolumn{14}{|l|}{ Methanosaetaceae } \\
\hline Methanosaeta & + & - & + & - & + & + & + & - & + & + & - & - & - \\
\hline Methanothermosaeta & + & + & - & - & - & + & - & - & + & + & - & - & - \\
\hline Methanopyraceae & + & - & - & - & & & & & & & & & \\
\hline
\end{tabular}

+ , present ; - , absent ; \pm , present or absent depending on genus or species. Ar, archaeol ; CA, caldarchaeol ; Hy, hydroxyarchaeol ; Mc, macrocyclic archaeol ; Glc, glucose ; Gal, galactose ; Man, mannose ; GlcNAc, $N$-acetylglucosamine ; Ino, inositol ; EtN, ethanolamine ; Ser, serine ; Gro, glycerol ; APT, aminopentanetetrol and its derivatives.

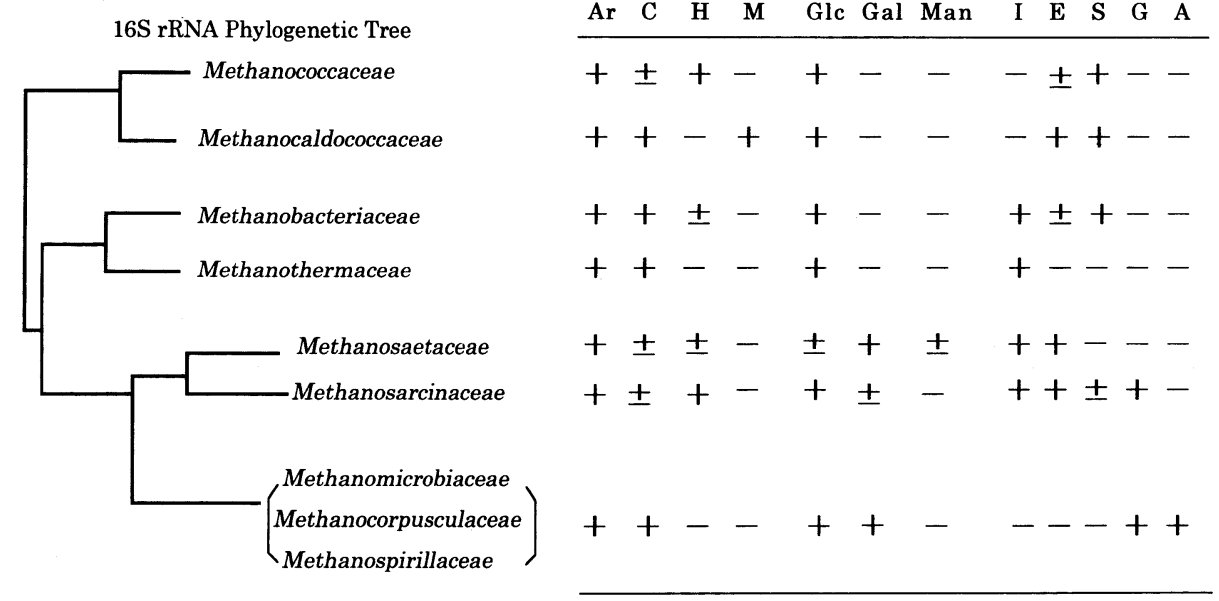

\begin{tabular}{|c|c|c|c|c|c|c|c|c|c|c|c|}
\hline \multicolumn{4}{|c|}{ Core } & \multicolumn{3}{|c|}{ Sugar } & \multicolumn{5}{|c|}{ PHG } \\
\hline Ar & C & $\mathrm{H}$ & M & Glc & Gal & Man & I & $\mathbf{E}$ & $\mathbf{S}$ & G & A \\
\hline+ & & + & - & + & - & - & - & \pm & + & - & - \\
\hline+ & + & - & + & + & - & - & - & + & + & - & - \\
\hline+ & + & \pm & - & + & - & - & + & \pm & + & - & - \\
\hline+ & + & - & - & + & - & - & + & - & - & - & - \\
\hline+ & & \pm & - & \pm & + & \pm & + & + & - & - & - \\
\hline+ & & + & - & + & \pm & - & + & + & \pm & + & - \\
\hline+ & + & - & - & + & + & - & - & - & - & + & + \\
\hline
\end{tabular}

Fig. 7 Coincidence of the Distribution of Lipid Component Parts in Families of Methanogens with Phylogentic Tree Constructed by 16 S rRNA Sequence Homolog $\mathrm{y}^{23)}$. 
しか分析していないので，これが科の特徴を全体的に表 現しているかどうか分からないが，分析した $M . f e r-$ vidusでは，コア脂質はアーキオールとカルドアーキ オールで, セリン, エタノールアミンがなく, 極性基は グルコースとイノシトールのみで, コア脂質に $\mathrm{H}$ 型構 造をとっているものと思われるテトラエーテル型の新規 化合物が見いだされた。

Methanococcaceae (中温性と中等度好熱性)：もと の分類による Methanococcaceae のメタン菌は $16 \mathrm{~S}$ rRNA でもコア脂質組成でも菌の生育至適温度のちが う3つのグループに分けられた。中温性と中等度好熱性 の Methanococcaceae のメタン菌のコア脂質はアーキ オールとヒドロキシアーキオール ( $\alpha$ 型と $\beta$ 型の両方 $)$ である。中等度好熱性の M. thermolithotrophicus の コア脂質はアーキオールとヒドロキシアーキオール $(\alpha$ 型と $\beta$ 型の両方）の他に, カルドアーキオールが加わ り, 3 種のコア脂質を持つ。 3 種のコア脂質を持つ古細 菌の例はあまり多くはない。そのため, この菌は Methanothermococcus という新属に再分類された。 なお, Methanococcaceae の脂質の糖はグルコースの み, リン酸エステルとしてはイノシトールがなく, エ夕 ノールアミン，セリンに加えて $N$-アセチルグリコサミ ンが共通に見いだされている。

Methanocaldococcaceae : もとの Methanococcus 属のメ夕ン菌のうち超好熱性のものはこの新しい科に分 類された。この科のメタン菌のコア脂質にはヒドロキシ アーキオールがなく, マクロサイクリックアーキオール がある。このコア脂質はこのグループだけに見いだされ る特有のものである。コア脂質の種類のこのような相違 と系統関係の相違はよく対応しており, 脂質部品分析結

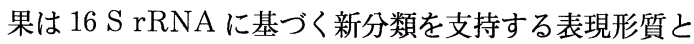
なっている。

Methanomicrobiaceae, Methanocorpusculaceae, および Methanospirillaceae :これらの科のメタン菌 の脂質は他の科のメタン菌と非常に異なっている。コア 脂質はアーキオールとカルドアーキオール，糖はグル コースとガラクトース, リン酸含有極性基には, 他の科 のメタン菌のようなイノシトール, エタノールアミン, セリンはなく, 新規化合物であるアミノペンタンテト ロールとそのジないしトリメチル化物とグリセロールが ある。これらの脂質部品分布はこの科のメタン菌の中で 全く例外なく同一である。なお, 高度好塩菌はメ夕ン菌 の中ではこの科と最も類縁性が高いといわれているが， 高度好塩菌の脂質の極性基に特徵的なグリセロールがこ の科のメタン菌にも共通していることは類縁性を裏付け るものである。

Methanosarcinaceae :この科のメタン菌は Methanomicrobiaceae のメタン菌とともに同じ目 (order)
である Methanomicrobiales に分類されていた。しか し，この科のメタン菌の脂質は Methanomicrobiaceae など 3 科のメ夕ン菌のそれとは全く異なってい る。この科のメタン菌のうち, メチル化合物からメタン 生成できるメタン菌 (Methanosarcina 属など) は, コア脂質ではカルドアーキオールは大部分の種で存在せ ず, $\beta$-ヒドロキシアーキオールがある。糖はグルコー スのみで, リン酸含有極性基はイノシトール, エ夕ノー ルアミン, セリンとグリセロールがあり，アミノペンタ ンテトロールはない。すべてに共通なアーキオールとグ ルコースを除くと, どちらかに存在する 8 種の脂質構成 部品のうち, 共通のものはグリセロールだけである。 Methanobacteriales と Methanococcales のメタン菌 のいずれかに存在する脂質構成部品 5 種のうち, 両科の メタン菌に共通しているのは 2 種であることを考える と, Methanomicrobiaceae と Methanosarcinaceae は異なる目に分類するべきである，と考えられ，ここで

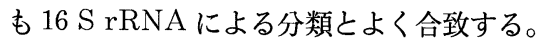

Methanosarcinaceae のうち, 酶酸だけからメタン を生成し，メチル化合物を利用できないグループのメ夕 ン菌 (Methanosaeta) はコア脂質が $\alpha$-ヒドロキシアー キオールで, 糖としてガラクトース, マンノースをもつ 点でMethanosarcina 属のメタン菌などと異なる。

このようにメタン菌における脂質の多様性を整理する ことができたが, この多様性はバラバラの無秩序で雑多 な多様性ではなく, メ夕ン菌の $16 \mathrm{~S}$ rRNA の塩基配列 の相同性に基づく系統関係を基礎にした分類と対応して おり，科または属レベルで共通性のある分布をしている ことが明らかになった ${ }^{23)}$ 。言い換えると, 脂質の多様 性は少なくともメタン菌において系統関係を反映し, 系 統関係によって決まっている，といえる。

\section{8 古細菌の生息温度と脂質構造の関係}

メタン菌あるいは古細菌のエーテル脂質あるいはテト ラエーテル脂質の存在意義を考察する議論で一般的なの は, その化学的安定性と, 多くの古細菌が極限環境に生 息していることを結びつけてこの脂質が極限環境への適 応の結果存在するのであるとするものである。しかし, 前節で詳しく調べたように, 脂質は生息環境よりは系統 ごとに同じ組成を示していて，例えば，環境の一要素で ある生息環境の温度（生育の至適温度）とは関係がな い。そのことを Table 2 に示す。テトラエーテル型の コア脂質であるカルドアーキオールをもつメタン菌を集 めて, 生育の至適温度の順に並べた。 $80^{\circ} \mathrm{C}$ 以上の超好 熱菌からメタン菌としては最低の生育温度の $23^{\circ} \mathrm{C}$ の Methanogenium cariaci まで好熱菌, 中温菌を問わ ず, 各種生育温度のメタン菌が等しくカルドアーキオー ルを持っている。つまり,テトラエーテル型脂質は高温環 
Table 2 Core Lipid Composition of Thermophilic and Mesophilic Methanogens that Contain Archaeol and Caldarchaeol.

\begin{tabular}{l|c|c|c|c|c}
\hline \multicolumn{1}{c|}{ Species } & $\begin{array}{c}\text { Opt. Growth } \\
\text { Temp. }\left({ }^{\circ} \mathrm{C}\right)\end{array}$ & Archaeol & Caldarchaeol & $\begin{array}{c}\text { Hydroxy } \\
\text { archaeol }\end{array}$ & $\begin{array}{c}\text { Cyclic } \\
\text { archaeol }\end{array}$ \\
\hline Mcc. jannaschii & 85 & + & + & - & + \\
Mtm. fervidus & 84 & + & + & - & - \\
Mba. thermoautotrophicum & 65 & + & + & - & - \\
Mtc. thermolithotrophicus & 65 & + & + & + & - \\
Mts. thermophila & 55 & + & + & - & - \\
Msl. zhilinae & 45 & + & + & + & - \\
Mcu. oldenburgensis & 42 & + & + & & - \\
Mba. formicicum & 37 & + & + & - & - \\
Mbr. arboriphilus & 37 & + & + & - & - \\
Mmi. mobile & 37 & + & + & - & - \\
Mcp. parvum & 37 & + & + & - & - \\
Msp. hungatei & 37 & + & + & - & - \\
Mge. cariaci & 23 & + & + & - & - \\
\hline
\end{tabular}

+, present ; -, absent. Mcc., Methanocaldococcus ; Mtm. Methanothermus ; Mba., Methanobacterium ; Mtc, Methanothermococcus ; Mts, Methanothermosaeta ; Msl., Methanosalsus ; Mcu., Methanoculeus ; Mbr., Methanobrevibacter ; Mmi., Methanomicrobium ; Mcp., Methanocorpusculum ; Mge., Methanogenium.

Table 3 Core Lipid Composition of Thermophilic and Mesophilic Archaebacteria that Contain Either Archaeol or Caldarchaeol.

\begin{tabular}{l|c|c|c|c|c}
\hline \multicolumn{1}{c|}{ Species } & $\begin{array}{c}\text { Temperature } \\
\left({ }^{\circ} \mathrm{C}\right)\end{array}$ & Archaeol & Caldarchaeol & $\begin{array}{c}\text { Hydroxy } \\
\text { archaeol }\end{array}$ & $\begin{array}{c}\text { Cyclic } \\
\text { archaeol }\end{array}$ \\
\hline Sul. solfataricus & 70 & + & + & - & - \\
Tpl. acidophilum & 55 & - & + & - & - \\
\hline Mpy. kandleri & 100 & + & - & - & - \\
Tco. celer & 88 & + & - & - & - \\
Hal. cutrubrum & 37 & + & - & - & - \\
\hline
\end{tabular}

+, present;-, absent. Sul, Solfolobus ; Tpl., Thermophasma ; Mpy., Methanopyrus ;

Tco., Thermococcus; Hal., Halobacterium.

境に適応したために出現したのではないであろう。また， 超好熱性古細菌でもテトラエーテル型のコア脂質を持た ず，アーキオールだけの古細菌も存在する (Table 3)。

このように古細菌のコア脂質の基本的な構成は温度と いう環境条件との相関関係はない，といえる。このこと は 1 種類の古細菌の生育温度を変えたときにコ予脂質組 成が量的に変動しない，ということを意味するものでは ない。ここで主に取り上げているのは，ある種の構造の 脂質を合成する能力をその菌が持っているかどうか, と いうことであって, どのくらいの量合成するかというこ とではない。

エーテル脂質が好熱性の古細菌に限ったものではない ことは，1で述べた。エーテル結合をもつ脂質はほとん どが中温性である真核生物にも, 中温性, 好熱性を問わ
ず真正細菌にも存在している。

テトラエーテル型脂質は，細胞膜においては膜を横断 した単分子膜を形成し，その分子の両端の 2 個の極性基 を膜の両側に出している，亡考えられている。このよう な両極性の橋かけ構造の脂質はエステル型脂質（当然そ れは真正細菌に存在する）にもある。中温性の嫌気性真 正細菌Butyrivibrio sp.の $\mathrm{C}_{32}$ のジカルボン酸（ジア ボリン酸 diabolic acid）をもつ複雑なプラスマローゲ ン型脂質がそれである ${ }^{24)}$ 。これと同じジアボリン酸は 超好熱性の真正細菌 Thermotoga 属細菌にも見いださ れている25)。

\section{9 グリセロリン酸脂質骨格の立体構造の意義}

地球上の生物の最も高いレベルの分類群は, $A r$ - 
chaea, Bacteria, Eucarya の 3 ドメインである。最近 の見解では，生化学的あるいは分子生物学的には，この うちの Archaea と Bacteria が基本的な二大系統であ り, Eucarya は Archaea と Bacteria のキメラまたは ハイブリッドとみられている26),27)。この二大系統にお けるグリセロ脂質の多様性の最も根本的なものはグリセ ロリン酸骨格の立体構造である。すなわち, 古細菌では G-1-P, 真正細菌では G-3-P である。これまで, 脂質 のさまざまな多様性（相違）が生物の属, 科あるいは目 などの系統分類群を分ける指標になることを述べてき た。最高レベルの分類群 (Archaea とBacteria) を識 別する脂質の指標は, グリセロリン酸骨格の立体構造で ある，と考えられる。2で述べた古細菌之真正細菌の脂 質の 4 つの特徴のうち, 3 つは, 上述したように, 例外 が見つかったので最も根本的なものとは思えない。

グリセロリン酸骨格は膜グリセロ脂質の背骨をなす基 本構造である。この化合物の立体異性体 (対掌体) はア キラルな物理化学的性質には影響せず, どちらの異性体 であっても膜をつくるという機能は果たせるはずであ る。しかし, 生合成的には, 2 つの対掌体に作用する醅 素は全く異なる酵素（遺伝子）ファミリーに属している ことが知られており ${ }^{28)}$, その一次構造は全く相同性がな い。このような䤃素は相互に突然変異で置き換わる，ま たは立体特異性を転換するということはあり得ず，膜脂 質のグリセロリン酸骨格は一度いずれかの対掌体を採用 した生物（古細菌あるいは真正細菌）はそれ以後変わる ことなくその立体構造を保持してきた，と考えられる。 ではグリセロリン酸骨格の対掌体は古細菌, 真正細菌に よっていつ採用されたのか。タンパク質のアミノ酸や糖 とは違って, 膜をつくるリン脂質は細胞が「小さな袋」 であるために不可欠の物質であることをここで想起すべ きである。一度出現して細胞に組み込まれたら不変であ り, かつ、これによって細胞が出発する物質である, と いうことを結びつけて考えれば，グリセロリン酸骨格は 細胞の出現とともに両対掌体があり，そのときに古細菌 と真正細菌の先祖の分化は始まった，と考えざるを得な い。これでは古細菌之真正細菌は共通の祖先細胞無しに 分化出現したことになり, 両者の生化学的共通性はどう 説明するか，という問題が生ずる。このことは本小文の 論題をはずれるので一言だけ, Wächtershäuser の表面 代謝体 ${ }^{29)}$,30)を共通祖先として想定することで説明でき ることをつけ加えておく。Wächtershäuser の表面代 謝体についてふれる余裕がないので, 引用文献 ${ }^{29), 30)}$ お よびその解説論文 ${ }^{31)}$ を参照されたい。

（受付：1997年 1 月 6 日, 受理 : 1997 年 1 月 27 日）

\section{文献}

1) L. A. Horrocks, "Ether Lipids", Academic Press,
New York (1972) p. 177.

2) D. C. Malins, U. Varanasi, "Ether Lipids", Academic Press, New York (1972) p. 297.

3) G. A. Thompson, Jr., "Ether Lipids", Academic Press, New York (1972) p. 313.

4) G. A. Thompson, Jr., "Ether Lipids", Academic Press, New York (1972) p. 321.

5) H. Goldfine, “Ether Lipids", Academic Press, New York (1972) p. 330.

6) T. A. Langworthy, G. Holzer, J. G. Zeikus, T. G. Tornabene, Syst. Appl. Microbiol., 4, 1 (1983).

7) R. Huber, T. Wilharm, T. Huber, A. Trincone, S. Burggraf, H. Konig, R. Rachel, I. Rockinger, H. Frick, K. O. Stetter, Syst. Appl. Microbiol., 15, 340 (1992).

8) M. Nishihara, H. Morii, Y. Koga, J. Biochem., 101, 1007 (1987).

9) C. R. Woese, O. Kandler, M. L. Wheelis, Proc. Ntnl. Acad. Sci. USA, 87, 4576 (1990).

10) T. A. Langworthy, J. L. Pond, Syst. Appl. Microbiol., 7, 253 (1986).

11) M. De Rosa, A. Gambacorta, A. Gliozzi, Microbiol. Rev., 50, 70 (1986).

12) A. Sugai, R. Sakuma, I. Fukuda, Y. Itoh, K. Kon, S. Ando, T. Itoh, Lipids, 30, 339 (1995).

13) M. De Rosa, A. Gambacorta, A. Trincone, A. Basso, W. Zillig, I. Holz, Syst. Appl. Microbiol., 9, 1 (1987).

14) Y. Sako, N. Nomura, A. Uchida, Y. Ishida, H. Morii, Y. Koga, T. Hoaki, T. Maruyama, Int. J. Syst. Bacteriol., 46, 1070 (1996).

15) T. A. Langworthy, "The Bacteria" Vol. 8, Academic Press, Orlando (1985) p. 459.

16) M. Kamekura, M. Kates, "Halophilic Bacteria" Vol. 2, CRC Press, Boca Raton, Florida (1988) p. 25.

17) M. Kates, N. Moldoveanu, L. C. Stewart, Biochim. Biophys. Acta, 1169, 46 (1993).

18) M. Torreblanca, F. Rodoriguez-Valera, G. Juez, A. Ventosa, M. Kamekura, M. Kates, Syst. Appl. Microbiol. 8, 89 (1986).

19) M. Kates, "The Biochemistry of Archaea (Archaebacteria)”, Elsevier, Amsterdam (1993) p. 261.

20) Y. Koga, M. Nishihara, H. Morii, M. AkagawaMatsushita, Microbiol. Rev., 57, 164 (1993).

21) M. Nishihara, H. Morii, Y. Koga, Biochemistry, 28, 95 (1989).

22) Y. Koga, M. Akagawa-Matsushita, M. Ohga, M. Nishihara, Syst. Appl. Microbiol., 16, 342 (1993).

23) D. R. Boone, W. B. Whitman, P. Rouviere, "Methanogenesis. Ecology, Physiology, Biochemistry \& Genetics”, Chapman \& Hall, New York (1993) p. 35.

24) N. G. Clark., G. P. Hazlewood, R. M. C. Dawson, Biochem. J., 191, 561 (1980).

25) M. De Rosa, A. Gambacorta, R. Huber, V. Lanzotti, B. Nicolaus, K. O. Stetter, A. Trincone, J. Chem. Soc., Chem. Commun., 1988, 1300. 
26) W. Zillig, Current Opinion in Genetics and Development, 1, 544 (1991).

27) A. Yamagishi, T. Oshima, "Chemical Evolution: Self-Organization of the Macromolecules of Life" A. Deepak Publishing, Hampton, VA (1995) p. 155.

28) H. Taguchi, T. Ohta, J. Biol. Chem., 266, 12588
(1991).

29) G. Wächtershäuser, Microbiol. Rev., 52, 452 (1988).

30) G. Wächtershäuser, Prog. Biophys. Molec. Biol., 58, 85 (1992).

31）古賀洋介, 科学, 66, 641 (1996). 


\title{
日本油化学会誌本号掲載 論文要旨
}

\section{［総説］＼cjkstart古細菌エーテル脂質の多様性と系統関係}

\author{
古 賀 洋 介 \\ 産業医科大学・医学部・生体物質化学教室 (T807 北九州市八幡西区医生が丘 1-1)
}

エーテル脂質は古細菌と真正細菌を区別する最も明確な指標のひとつである。古細菌の中では, コア脂質の構 造，リン酸含有極性頭部基，糖脂質の糖残基の種類に多様性が認められる。例えば，非メ夕ン生成好熱菌は主にテ トラエーテル型のコア脂質を含み, リン酸含有極性基としてはイノシトールだけを持っており，高度好塩菌の脂質 はジエーテル型のコア脂質と極性頭部基としてはグリセロリン酸およびその誘導体のみから成っている。メタン菌 の脂質はこれまで分析された限りではすべて極性基として窒素原子含有基を持っている。このような古細菌の脂質 の多様性はランダムなものではなく，系統関係によって決定されているので，定性的な脂質組成は高度好塩基やメ タン菌で化学分類学的マーカーとして用いられている。生物の世界の最高階級である二つのドメインである古細菌 と真正細菌を分ける最も基本的な表現形質は極性脂質のグリセロリン酸骨格の対掌体構造である。この相違はこの 二つのドメインが分化した時点以来ずっと保たれていたと仮定することができる。

（連絡者：古賀洋介）Vol. 46, No. 5, 485 (1997)

[総説 $]$

\section{好熱性古細菌のエーテル脂質}

\author{
須 貝 昭 彦 \\ 北里大学一般教育総合センター化学研究室 (广228 相模原市北里 1-15-1)
}

常温で生育する古細菌の脂質は, 基本的にはグリセリンの $s n-2$ と $s n-3$ に $\mathrm{C}_{20}$ のフィタノールがエーテル結合 した archaeol であるが，高温下で生育する菌株では，2 分子の archaeol が炭化水素同士を向き合い，炭化水素鎖 のメチル末端が結合した構造の caldarchaeol を基本構造とするものが多い。好熱性古細菌は, 強酸性下に生息す るものと, 中性付近に生息しているものとに分けることができるが, 強酸性下で生育するものでは, 全てテトラ エーテル型脂質を主要とするものからなっている。これに対し, 中性で生育するものでは, テトラエーテル型脂質 を主要なものとするものの他に，ジエーテル型脂質を主要脂質上する菌株も検出されている。特に強酸性高温下に 生育するSulfolobaceae 科に属する菌株の主要脂質は, caldarchaeol の片側のグリセリンがカルジトールと置き 換わった calditocaldarchaeol を脂質骨格としており，この特殊な構造が耐酸耐熱性に寄与している可能性が考 えられる。また，好熱性古細菌の脂質におけるリンを含む極性頭部は，イノシトールリン酸などの負電荷のものか らなっている。 (連絡者: 須貝昭彦) Vol. 46, No. 5, 497 (1997)

\section{[総説 $]$}

\section{エーテル脂質生合成の初期段階}

\author{
西 野 徳 三 \\ 東北大学工学部 (
}

古細菌の膜脂質は他の生物の膜脂質がリン脂質のエステル型であるのに対しエーテル型脂質であり，それらの生 物が過酷な条件においても生育できることを可能にしている。これらの脂質はグリセロールに $\mathrm{C}_{20}$ や $\mathrm{C}_{40}$ の飽和 イソプレン（フィタニル基やジフィタニル基）が結合している。 